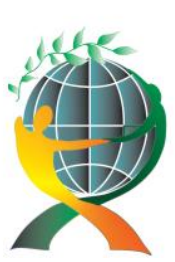

\author{
(online) $=$ ISSN $2285-3642$ \\ ISSN-L = $2285-3642$ \\ Journal of Economic Development, Environment and People \\ Volume 10, Issue 3, 2021 \\ URL: http://jedep.spiruharet.ro \\ E-mail : office jedep@spiruharet.ro
}

\title{
Sustaining Psychological Wellbeing amongst Married Career Women: Psychological Distress, Social Support, Domestic Violence, and Family Conflict Resolution as Influencers
}

\author{
Foluso Philip Adekanmbi ${ }^{1}$, Steve Olusegun Adegoke ${ }^{2}$, Wilfred Isioma Ukpere ${ }^{3[}$ \\ and Lovlyn Ekeowa Kelvin-lloafu ${ }^{4}$ \\ ${ }^{1}$ Department of Industrial Psychology and People Management, College of Business \& Economics, \\ University of Johannesburg, South Africa \\ ${ }^{2}$ Department of Psychology, Faculty of the Social Sciences, University of Ibadan, Nigeria \\ ${ }^{3}$ Department of Industrial Psychology and People Management, College of Business \& Economics, \\ University of Johannesburg, South Africa. \\ ${ }^{4}$ Department of Management, Faculty of Business Administration University of Nigeria, Enugu Campus
}

\begin{abstract}
The current paper examines the influencing factors in sustaining psychological wellbeing amongst married career women in Ibadan, Nigeria. Hence, this paper proposes increasing and sustaining psychological wellbeing amongst married career women in Ibadan, Nigeria. The paper espoused a quantitative research approach based on a survey research design. The results showed that psychological distress, social support, domestic violence, and family conflict resolution significantly jointly and independently influence psychological wellbeing among married career women in Ibadan, Nigeria. The results show that family conflict resolution is a noteworthy moderator of the negative influence of psychological distress and domestic violence in sustaining psychological wellbeing amongst married career women in Ibadan, Nigeria. Besides, the outcomes indicate that religion significantly influences psychological wellbeing amongst married career women in Ibadan, Nigeria. Therefore, developmental psychologists, organizational managers, human resources practitioners, counselors, and religious organizations should encourage reducing psychological distress by increasing social support, reducing domestic violence, and achieving consistent conflict resolution within families. This step will sustain psychological wellbeing amongst married career women in Nigeria. Thus, this paper has recognized psychological distress, social support, domestic violence, family conflict resolution, and demographic factors (for instance, religion) as significant influencers in sustaining psychological wellbeing amongst married career women in Ibadan, Nigeria.
\end{abstract}

Keywords: Sustenance, marriage, career, women, influence, psychological wellbeing, Ibadan, Nigeria

JEL Codes: 131

How to cite: Adekanmbi, F., Adegoke, S., Ukpere, W., \& Kelvin-lloafu, L. (2021). SUSTAINING PSYCHOLOGICAL WELLBEING AMONGST MARRIED CAREER WOMEN: PSYCHOLOGICAL DISTRESS, SOCIAL SUPPORT, DOMESTIC VIOLENCE, AND FAMILY CONFLICT RESOLUTION AS INFLUENCERS. JournaI of Economic Development, Environment and People, 10(3), 5-25. doi: http://dx.doi.org/10.26458/jedep.v10i3.700 


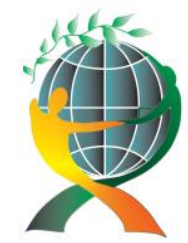

\author{
(online) $=$ ISSN $2285-3642$ \\ ISSN-L = $2285-3642$ \\ Journal of Economic Development, Environment and People \\ Volume 9, Issue 2, 2019 \\ URL: http://jedep.spiruharet.ro \\ E-mail : office jedep@spiruharet.ro
}

\title{
1. Introduction
}

The psychological wellbeing of employees has sustained the attraction of significant concern and attention by psychologists and human resources managers because every organization needs employees in an excellent psychological state to flourish and endure the constant changes in the world of work (Ferreira, 2012). However, psychological wellbeing among married career women remains a determining factor influencing the success and failure of various homes today as the world is experiencing changes in the organizational structure. As George (2001) said, marriage is exclusively suitable for conceiving and raising children by obtaining both parents' input in the enduring union. Besides, marriage plays a part in shielding loving relationships (Brake, 2011); therefore, any condition that is not favorable to couples' wellbeing will intensely and adversely hit the family health and relationship (Hartley \& Watson, 2012). The Longman Dictionary of Contemporary English (2017) noted that psychological wellbeing is an optimistic physical, mental, and social wellbeing state. Psychological wellbeing is the absence of illness and a complete state of mental, physical, and social wellbeing (World Health Organization, 2012). Therefore, this led to a change in focus from an overemphasis of the medical model towards developing a public health model (Edmondson \& Macleod, 2015). Findings indicate that working women face intense, stressful conditions as they need to live up to the duties of faithful wives, obedient daughters-in-law, sacrificing mothers, and simultaneously struggle to become dynamic, committed, and competitive career women (Parveen, 2009). Harshpinder (2006) opined that a significant number of working women experienced more psychological and physiological stress. Besides, the research noted women's employment as either detrimental or beneficial to women's psychological wellbeing. Therefore, a stable day-to-day lifestyle and jobs positively influence career women (Srimathi, 2010).

Psychological distress is an unpleasant feeling or emotion that can unfavorably impact one's functioning, encompassing depression, distraction, anxiety, and states of marked impairment (Mirowsky \& Ross, 2007). The emotional suffering in a stressful situation makes it challenging to cope with usual daily activities and negatively impacts focus and social activities (Mirowsky \& Ross, 2007). Also, Lorenzo-Blanco et al. (2017) opined that it is quite disturbing that stress is present in just about everyone, but it is common for couples because they are still learning to adjust to marital life. Psychological distress can impact overall health and put one at a higher risk of chronic diseases, including cardiovascular. One of the possible consequences of severe psychological distress is the increased risk of suicide (Brandberg, Bolund \& Sigurdardotti, 1992). Besides, research indicated that most married couples with reports of psychological distress and people with severe depression are significantly more at risk of developing suicidal thoughts, implying that psychological distress should be more of a clinical issue than social (Brandberg et al., 1992).

Furthermore, social support is the perception and actuality that an individual receives some assistance and care from people and is involved in an active social system. These practical means can be in the form of information (for instance, pieces of advice), companionship (for example, sense of belonging), emotion (nurturing), or financial assistance (Thomas, Liu \& Umberson, 2017). This care or help can come from several sources: friends, family, government, and organizations. For instance, the government could provide social care in public aid. Nevertheless, studies on social support have gone across disciplines, including psychology, public health, medicine, nursing, human resources management, and social work. Besides, social support 


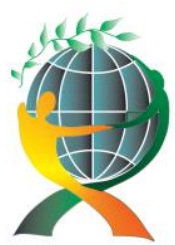

\author{
(online) = ISSN $2285-3642$ \\ ISSN-L = $2285-3642$ \\ Journal of Economic Development, Environment and People \\ Volume 10, Issue 3, 2021 \\ URL: http://jedep.spiruharet.ro \\ E-mail : office jedep@spiruharet.ro
}

inspires many physical and mental health benefits (Mone et al., 2011). Hence, this paper's social support among married career women is the self-perception of overall family, friends, and relatives' supports for individual survival or social aspects. The provision of social support positively adds to the wellbeing of working women in all settings. Besides, working women depend on the social support they get through various relationships, developed in both their professional and personal roles, to achieve work-family balance as social support mitigates work-family conflict, positively improves health, and reduces stress (Cutrona et al., 1994; Deelstra et al., 2003).

Domestic violence denotes offensive behavior, physical and psychological, by a significant other against another in a close relationship, such as family, cohabitation, marriage, or dating (Cunradi et al., 2014). Domestic violence is a significant public wellbeing worry for women living in developed and developing nations across the globe (Tjaden \& Thoennes, 2000). Golding's (1999) study on the relationship between domestic violence and psychological wellbeing amongst 640 women indicated that, on average, occurrence rates for quantifiable depression amongst abused women were $48 \%$ across 18 studies. Besides, the severity of violence is linked with the pervasiveness of depression and worsening psychological wellbeing (World Health Organization, 2000). Also, Fawole, Aderonmu, and Fawole (2005) concluded that exposure to domestic violence is a common phenomenon in Ibadan, Nigeria, across the low-density areas. Exposure to domestic violence is as psychologically debilitating to witness and the victim.

Moreover, family conflict resolution remains a social circumstance where disagreeing parties in a voluntary agreement decide to peaceably live with one another, dissolving their fundamental inharmoniousness and henceforth stop to raise forces against one another (Wallensteen, 2015). Resolving family conflict teaches kids how to negotiate and reach compromises, setting them up for healthy relationships. Therefore, disagreements are a normal part of family life. Lee and Lee (2015) concluded that a devastating conflict resolution style in the family always harms psychological wellbeing and reduces inputs from both parties. Besides, Dreu and Beersma (2005) believe that when not appropriately resolved, family conflict may affect one's self-esteem and emotions connected to the conflict, such as hatred, anger, fear, and need.

As earlier indicated, the psychological wellbeing of married working women remains an essential factor to consider, as every organization needs its employees to be in an excellent psychological state to flourish and endure the constant changes in the world of work. Besides, there are many determinants of women's psychological wellbeing variations, specifically the married career women (Ryff, 2014). However, there are virtually very few published investigations on achieving and sustaining the psychological wellbeing of married career women in Nigeria through the combination of psychological distress, social support, domestic violence, and family conflict resolution as influencers. Hence, indicating factors that could influence psychological wellbeing sustenance amongst married women in Nigeria demands scholarly attention.

\title{
2. Aims
}

The current paper aims to look into sustaining the psychological wellbeing of married career women in Nigeria by examining psychological distress, social support, domestic violence, and family conflict resolution as influencers, with an intent to propose strategies for achieving and sustaining the psychological wellbeing of married career women in Nigeria. Hence, the objectives of the current paper are: 


\author{
(online) $=$ ISSN $2285-3642$ \\ ISSN-L = $2285-3642$ \\ Journal of Economic Development, Environment and People \\ Volume 9, Issue 2, 2019 \\ URL: http://jedep.spiruharet.ro \\ E-mail : office jedep@spiruharet.ro
}

- To examine relationships among psychological distress, social support, domestic violence, family conflict resolution, and psychological wellbeing amongst married career women in Ibadan, Nigeria;

- Investigate psychological distress, social support, domestic violence, and family conflict resolution as influencing factors for sustaining psychological wellbeing amongst married career women in Ibadan, Nigeria;

- Find out if family conflict resolution will significantly moderate psychological distress, social support, and domestic violence in achieving and sustaining psychological wellbeing amongst married career women in Ibadan, Nigeria; and

- To determine demographic factors (such as age, religion, marital status, and educational qualifications) as influencing factors for sustaining psychological wellbeing amongst married career women in Ibadan, Nigeria.

\title{
3. Literature Review
}

The literature review of this paper deals specifically with constructs such as psychological distress, social support, domestic violence, family conflict resolution, and psychological wellbeing.

\subsection{Psychological Distress, Social Support, Domestic Violence, Family Conflict Resolution, and Psychological Wellbeing}

Research has established that psychological distress is a significant predictor of psychological wellbeing, having harmful effects on individuals' health and wellbeing (Frone et al., 1997). Mark and Smith (2012) studied the relationship between psychological distress and coping in predicting employees' psychological wellbeing levels. They posited that poor wellbeing correlates with increased levels of psychological distress. Besides, deep psychological distress negatively correlates with psychological wellbeing, while high motivation positively associates with it. Hence, their findings demonstrated the importance of employees' psychological distress in predicting their psychological health. Research has shown that psychological distress significantly reduces psychological wellbeing while work-life balance significantly and positively predicts psychological wellbeing and a healthy lifestyle (Jackson \& Slater 2016). Empirical evidence confirms that psychological distress and work-family balance predicted a $67.3 \%$ psychological wellbeing variance (Karatepe \& Tekinkus, 2006). Employees with a low level of psychological distress perform splendidly at work and report healthy lifestyles and improved psychological wellbeing (Maslach \& Leiter, 2014). Mohammed et al. (2010) found that physical exercise, deep psychological distress, and work-life balance predictors psychological wellbeing (PW). Besides, Lee, Tzeng, and Chiang (2019) study indicated reduced psychological distress (PD) as the primary predictor of nurses' psychological wellbeing Caverley (2005) showed that distressed employees are more likely to be weak and less motivated less safe at work, and unhealthy, affecting their psychological and emotional wellbeing

The above literature has, therefore, triggered the following hypothesis:

$\boldsymbol{H}_{1:}$ Psychological distress significantly influences psychological wellbeing's sustenance amongst married career women in Ibadan, Nigeria.

Regarding social support, a study conducted by Mone et al. (2011) concluded that when divorced parents remarry, apart from its positive psychological impact, several changes influence the children involved in the 


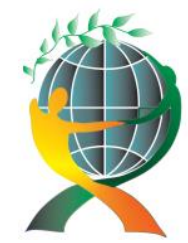

\author{
(online) $=$ ISSN $2285-3642$ \\ ISSN-L = $2285-3642$ \\ Journal of Economic Development, Environment and People \\ Volume 10, Issue 3, 2021 \\ URL: http://jedep.spiruharet.ro \\ E-mail : office jedep@spiruharet.ro
}

relationship. Hence, the step-parent's additional support can help an individual's emotional wellbeing (Mone et al., 2011). Besides, their study indicated that social support predicted psychological wellbeing among married women. Studies showed that social support (SS) from friends and family increases physiopsychological wellbeing and decreases stress among working women (Ryska \& Yin, 1999; Reed \& Giacobbi, 2004; Malinauskas, 2010). Specifically, women's social support systems seriously influence their psychological wellbeing in different ways (Feldman et al., 2000). In addition, numerous parts of significant social care, such as emotional bonds, attending social events, family/friends contacts, couple focused, and remittances from children, are significantly related to improved psychological wellbeing (Gyasi et al., 2018). Adejumo (2008) noted a significant independent influence of SS on the PW of career women in Ibadan, Nigeria. Social support positively impacts the occupied roles of women at workplaces by creating an equilibrium between family and work, making them ardently proficient, thus abolishing family-work struggles and enhancing psychological wellbeing (Afroz, 2016). The findings of Oluwagbemiga (2016) indicated that social support (companionship, emotional support, financial support, and information access) has a significant effect on the psychosocial wellbeing of the elderly in older peoples' homes in Ibadan, Nigeria.

The following hypothesis comes from this literature:

$\boldsymbol{H}_{2}$ : Social support significantly influences psychological wellbeing's sustenance amongst married career women in Ibadan, Nigeria.

Domestic violence has contributed significantly to the low psychological wellbeing among married couples in the southwestern part of Nigeria (Adebayo, 2014). Besides, Afolabi and Aina (2014) concluded that a high level of family stress and domestic violence contributed to a low level of wellbeing among spouses and children. Also, Scott and Marshall (2009) examined the relationship between domestic violence and psychological wellbeing among married couples and indicated a substantial negative correlation between the two variables. Their findings revealed that increased domestic violence reduced psychological wellbeing. Also, Sugarman and Hotaling (1997) reported that as family dysfunction and domestic violence increase, psychological wellbeing becomes significantly reduced. When individuals fail to achieve their goals due to perceived domestic violence or restraint by family or society, they encounter an increased level of stress, leading to psychological distress (Field \& Caetano, 2004).

Hence, the information above has prompted the following hypothesis:

$\boldsymbol{H}_{3:}$ Domestic violence significantly influences psychological wellbeing's sustenance amongst married career women in Ibadan, Nigeria.

Regarding family conflict resolution, psychological wellbeing research and the introduced social interaction studies on family lifestyle showed that family conflict resolution was a moderating factor that suppressed partner violence and aggression on psychological wellbeing (Cole et al., 2002). Family conflict causes disturbance and the disintegration of relationships, but ineffective management yields undesirable results (Kreitner \& Kinicki, 2005). According to Sori (2007), family conflict resolution had a significant independent effect on married women's psychological wellbeing enhancing their sense of security, trust, and psychological wellbeing due to support received and conflict resolution therapy. Panatik et al. (2011) noted a substantial positive correlation between conflict resolution and the psychological wellbeing of the family, and Reich et al. (2007) reported a significant relationship between the right conflict management style and psychological 


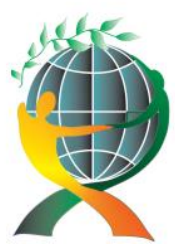

\author{
(online) $=$ ISSN $2285-3642$ \\ ISSN-L = $2285-3642$ \\ Journal of Economic Development, Environment and People \\ Volume 9, Issue 2, 2019 \\ URL: http://jedep.spiruharet.ro \\ E-mail : office jedep@spiruharet.ro
}

wellbeing within the family. In addition, in his study, Amiri (2006) indicated that family conflict resolution was a moderator of psychological wellbeing

The above literature has thus elicited the following hypothesis:

$\boldsymbol{H}_{4:}$ Family conflict resolution significantly influences psychological wellbeing among married career women in Ibadan, Nigeria.

Furthermore, the pieces of literature stated above have inspired the following hypotheses:

$\boldsymbol{H}_{5:}$ There are significant relationships amongst the psychological distress, social support, domestic violence, family conflict resolution, and psychological wellbeing of married career women in Ibadan, Nigeria.

$\boldsymbol{H}_{6:}$ Family conflict resolution significantly moderates psychological distress, social support, and domestic violence in sustaining the psychological wellbeing amongst married career women in Ibadan, Nigeria.

Concerning demographic factors, Al-Windi et al. (1999) noted that the occurrence of most symptoms of declining psychological wellbeing increased with age. Hence, the older the participants, the more they experience declining psychological wellbeing. In contrast, Lincoln et al. (2010) opined that respondents of advanced age reported higher psychological wellbeing levels than their younger counterparts. Dorji, Dunne, and Gurung (2020) posited a statistically significant relationship between marital status and psychological wellbeing. They further indicated that higher psychological wellbeing mean score was reported amongst married participants compared to single, separated, or widowed participants. In addition, in their study, Khumalo, Temane, and Wissing (2012) noted a positive correlation between education and psychological wellbeing. They opined that people with some tertiary level education obtained the highest mean scores on psychological wellbeing. In contrast, those without a lower education level or those without any formal education scored the lowest. Besides, Keyes (2002) indicated that education is positively associated with psychological health. Moreover, the relationship between religion and psychological wellbeing has been the center of many empirical investigations over the last 20 years. Several studies have indicated that many forms of religious experience are associated with improved psychological health (Francis \& Kaldor, 2002; Keyes \& Reitzes, 2007). Moreover, most studies' frequency of attendance at religious services correlated with greater psychological wellbeing (Francis \& Kaldor 2002; Keyes \& Reitzes 2007; Greenfield \& Marks 2007). Hence, religion has been linked to physical and mental wellbeing (Pargament et al., 2001; Wink et al., 2005; Greenfield \& Marks, 2007; Keyes \& Reitzes, 2007).

The above literature has, therefore, prompted the following hypothesis:

$\boldsymbol{H}_{7:}$ Demographic factors (such as age, religion, marital status, and educational qualifications) jointly and independently influence the sustenance of psychological wellbeing amongst married career women in Ibadan, Nigeria. 


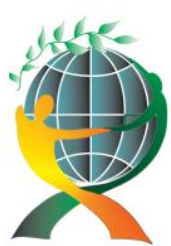

\author{
(online) $=$ ISSN $2285-3642$ \\ ISSN-L = $2285-3642$ \\ Journal of Economic Development, Environment and People \\ Volume 10, Issue 3, 2021 \\ URL: http://jedep.spiruharet.ro \\ E-mail : office jedep@spiruharet.ro
}

\section{Methods}

The current paper adopted a cross-sectional survey research design and a quantitative research approach to investigate how the psychological wellbeing of married career women in Ibadan, Nigeria, is influenced by psychological distress, social support, domestic violence, and family conflict resolution. Therefore, the present researcher gathered data through a self-administered instrument, namely, a questionnaire (Babbie \& Mouton, 2010). Furthermore, the participants of this paper included 300 participants (married career women) attending religious and social gatherings such as churches, mosques, and open/closed markets within Lagelu Local Government Area in Ibadan, Oyo State, and some other Ibadan locations. Hence, the research locations include Anifalaje and Akobo Ojuirin areas in Ibadan - during a religious and social gathering), Oloruntedo, off Olorundaaba, Ibadan, Adamasingba, Dugbe, Ibadan, Jegede, off Olorunsogo, Ibadan, and Akobo, Ibadan.

\subsection{Instrumentation}

The questionnaire used in measuring the constructs under study comprised different segments.

\section{Section A: Demographic Questions}

This section is for the participants' demographic data (age, educational qualification, profession, ethnicity, and family system - joint and nuclear).

\section{Section B: Psychological Distress (PD)}

The present researcher adapted a 10-item scale of psychological distress developed by Kessler et al. (2002) and validated by Bougie et al. (2016). The initial Cronbach's alpha of the 10-item scale was 0.89 . This scale consists of a five-scale Likert format of all of the time (4), most of the time (3), some of the time (2), a little of the time (1), and none of the time (0); respondents will indicate how often they experienced these symptoms using this measure. In the current investigation, the researcher realized a Cronbach's alpha coefficient of 0.93 for the reliability of this scale.

\section{Section C: Perceived Social Support (PSS)}

This 12-item measure of perceived social support system was developed by Zimet et al. (1988), having a Cronbach's alpha of 0.85 . The response format for the scale consisted of a 5-point Likert type ranging from strongly disagree (1) to strongly agree (5). The reliability of this scale, in this paper, is Cronbach's alpha coefficient 0.97 .

\section{Section D: Domestic Violence (DV)}

In measuring domestic violence in the present investigation, the current investigator adopted a 42 -item SelfReport Inventory developed initially by Abolmaali et al. (2014), which comprises a five-point Likert format ranging from 0 to 4 . The initial Cronbach's alpha of the 42 -item scale was 0.84 , while the Cronbach's alpha coefficient for the reliability of this scale in the present investigation is 0.98 .

\section{Section E: Family Conflict Resolution (FCR)}

The present researcher adopted a 17-item self-report measure developed by Tyler, Paul, and Megan (2010), to assess the rate of family conflict resolution. The initial Cronbach's alpha of the 17 -item scale was 0.82 . This scale consists of a five-scale Likert format rated 1 (strongly disagree) to 5 (strongly agree). In the current investigation, the researcher realized a Cronbach's alpha coefficient of 0.98 for the reliability of this scale. 


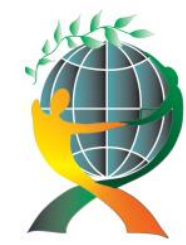

\author{
(online) $=$ ISSN $2285-3642$ \\ ISSN-L = $2285-3642$ \\ Journal of Economic Development, Environment and People \\ Volume 9, Issue 2, 2019
}

URL: http://jedep.spiruharet.ro

E-mail : office jedep@spiruharet.ro

Section F: Psychological Wellbeing (PW)

This 22-item measuring instrument developed by Flanagan, Van Heck, and Vingerhoets (2001) was adopted to measure married career women's psychological wellbeing. It had a Cronbach's alpha of 0.86 . The scale's response format contained a 5-point Likert type stretching from a little of the time (1) to all of the time (5). The reliability of this instrument in this paper is Cronbach's alpha coefficient 0.87 .

To validate the efficiency of the measuring scales, the current researcher adopted a pilot study to detect, beforehand any possible hitches. Besides, the present researcher assured that participants' anonymity was well-maintained in the inquiry process, including the primary research. The current researcher retrieved a total number of 280 valid questionnaires, and these questionnaires were analyzed.

The study adopted a multi-stage sampling technique. A multi-stage sampling method involves using different sampling techniques, which include: purposive method in which only married women were involved. In contrast, the current researcher applied a randomized questionnaire administration (for instance, a situation whereby the participants come in an organized manner, odd, and even number) method in the current study. However, the accidental sampling technique was used when the current researcher accidentally identified potential participants.

\title{
5. Results
}

The current researcher utilized the statistical package for social sciences (SPSS $\vee 26$ ) in analyzing the data sieved from the respondents. The current researcher inspected and cleaned the retrieved data before proceeding to the analysis. This paper presents the current results:

\section{Inferential Statistics (Hypothesis testing)}

Table 1: Multiple regressions showing the sustenance psychological wellbeing of married career women in Ibadan,

Nigeria, as influenced by psychological distress, social support, domestic violence, and family conflict resolution

\begin{tabular}{|c|c|c|c|c|c|c|c|}
\hline Influencers & $\mathbf{B}$ & $\mathbf{T}$ & $\mathbf{P}$ & $\mathbf{R}$ & $\mathbf{R}^{2}$ & $\mathbf{F}(\mathbf{4 , 2 7 5 )}$ & $\mathbf{P}$ \\
\hline $\begin{array}{c}\text { Psychological } \\
\text { Distress }\end{array}$ & .107 & 2.125 & .009 & & & \\
\hline Social Support & .677 & 8.123 & .000 & & \multirow{2}{*}{.478} & .229 & $<.40$ \\
\hline $\begin{array}{c}\text { Domestic } \\
\text { Violence }\end{array}$ & .099 & 1.809 & .016 & & & $<.01$ \\
\hline $\begin{array}{c}\text { Family Conflict } \\
\text { Resolution }\end{array}$ & .361 & 4.394 & .000 & & & \\
\hline
\end{tabular}

Dependent Variable: Psychological Wellbeing

Hypothesis one 


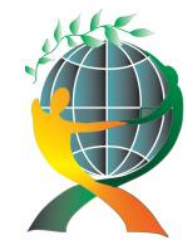

\author{
(online) $=$ ISSN $2285-3642$ \\ ISSN-L = $2285-3642$ \\ Journal of Economic Development, Environment and People \\ Volume 10, Issue 3, 2021 \\ URL: http://jedep.spiruharet.ro \\ E-mail : office jedep@spiruharet.ro
}

This proposition stated that psychological distress significantly influences psychological wellbeing among married career women in Ibadan, Nigeria. This hypothesis was tested using multiple regression analysis. The results are in Table 1 above.

The results in Table 1 showed the significant independent influence of each independent variable on the variance in the psychological wellbeing of married career women in Ibadan, Nigeria. The current results show that psychological distress contributed to an $11 \%$ variance in psychological wellbeing $(\beta=.107, t=2.125$; $\mathrm{p}<.01)$. Therefore, the overall results of this paper largely supported its first hypothesis.

\title{
Hypothesis two
}

This hypothesis stated that social support significantly influences psychological wellbeing sustenance amongst married women in Ibadan, Nigeria. This conditional statement was tested using multiple regression analysis, and the results are stated in Table 1 above.

Nonetheless, the results in Table 1 revealed the significant independent influence of each independent variable on the variance in the psychological wellbeing of married career women in Ibadan, Nigeria. However, the present results show that social support contributed about a $68 \%$ change in psychological wellbeing $(\beta=$ $.677, t=8.123 ; p<.05)$. Thus, the overall results of the current study factually supported its second hypothesis.

\section{Hypothesis three}

This hypothesis stated that domestic violence significantly influences psychological wellbeing among married career women in Ibadan, Nigeria. This proposition was tested using multiple regression analysis, and the results are stated in Table 1 above.

The results in Table 1 showed the significant independent influence of each independent variable on the variance in the psychological wellbeing of married career women in Ibadan, Nigeria. Nevertheless, the current results show that domestic violence contributed about a $10 \%$ variation in the psychological wellbeing amongst married career women in Ibadan, Nigeria $(\beta=.099, t=1.809 ; p<.01)$. Therefore, the general results of this paper supported its third hypothesis.

\section{Hypothesis four}

This proposition stated that family conflict resolution significantly influences psychological wellbeing among married career women in Ibadan, Nigeria. This hypothesis was tested using multiple regression analysis, and the outcomes are stated in Table 1 above.

However, the results in Table 1 showed the significant independent influence of each independent variable on the variance in the psychological wellbeing of married career women in Ibadan, Nigeria. Nevertheless, the current results indicate that family conflict resolution contributed about a $36 \%$ change in the psychological wellbeing amongst married career women in Ibadan, Nigeria $(\beta=.361, t=4.394 ; p<.01)$. Hence, the overall findings of this paper supported its fourth hypothesis.

Results showed in Table 1 further indicated that psychological distress, social support, domestic violence, and family conflict resolution significantly and jointly influence the sustenance of psychological wellbeing 


\author{
(online) $=$ ISSN $2285-3642$ \\ ISSN-L = $2285-3642$ \\ Journal of Economic Development, Environment and People \\ Volume 9, Issue 2, 2019
}

URL: http://jedep.spiruharet.ro

E-mail : office jedep@spiruharet.ro

amongst married career women in Ibadan, Nigeria $\left(R=.478, R^{2}=.229, F(4,275)=20.40, p<.01\right)$. This result infers that psychological distress, social support, domestic violence, and family conflict resolution accounted for $23 \%$ of the observed changes in the self-reported level of psychological wellbeing amongst married career women in Ibadan, Nigeria. In comparison, the remaining $76.7 \%$ is attributed to other factors not considered in this study.

Table 2: Zero Order Correlations showing the relationship amongst the psychological distress, social support, domestic violence, family conflict resolution, and psychological wellbeing of married career women in Ibadan, Nigeria.

\begin{tabular}{|l|l|l|l|l|l|l|l|}
\hline Variables & $\begin{array}{l}\text { Psychological } \\
\text { Distress }\end{array}$ & $\begin{array}{l}\text { Social } \\
\text { Support }\end{array}$ & $\begin{array}{l}\text { Domestic } \\
\text { Violence }\end{array}$ & $\begin{array}{l}\text { Family Conflict } \\
\text { Resolution }\end{array}$ & $\begin{array}{l}\text { Psychological } \\
\text { Wellbeing }\end{array}$ & Mean & SD \\
\hline $\begin{array}{l}\text { Psychological } \\
\text { Distress }\end{array}$ & 1 & $-.207^{* *}$ & $.237^{* *}$ & .085 & $-.126^{*}$ & 30.55 & 9.00 \\
\hline Social Support & & 1 & -.077 & $.758^{* *}$ & $410^{* *}$ & 36.48 & 18.72 \\
\hline $\begin{array}{l}\text { Domestic } \\
\text { Violence }\end{array}$ & & 1 & -.106 & .111 & 95.35 & 38.73 \\
\hline $\begin{array}{l}\text { Family Conflict } \\
\text { Resolution }\end{array}$ & & & & 1 & $.162^{* *}$ & 48.55 & 26.46 \\
\hline $\begin{array}{l}\text { Psychological } \\
\text { Wellbeing }\end{array}$ & & & & 1 & & 64.48 & 15.13 \\
\hline
\end{tabular}

*Correlation is significant at the 0.05 level (1-Tailed)

**Correlation is significant at the 0.01 level (1-Tailed)

\title{
Hypothesis five
}

This hypothesis stated a significant relationship between psychological distress, social support, domestic violence, family conflict resolution, and the psychological wellbeing of married career women in Ibadan, Nigeria. This study tested this hypothesis using a Zero-Order correlation, and the results are in Table 2 above.

From Table 2, the result matrix shows that psychological distress has a significant negative relationship with psychological wellbeing $(r=-0.13 ; p<.05)$. Hence, an increase in the psychological distress of married career women in Ibadan, Nigeria, will decrease their psychological wellbeing. Results also reveal that social support has a substantial positive correlation with an individual's psychological wellbeing $(r=0.41 ; p<.01)$. This outcome means that an increase in the social support married career women in Nigeria receive, the higher their psychological wellbeing. However, the current results indicate that domestic violence had no significant relationship with psychological wellbeing at $(r=0.11 ; p>.01)$. Besides, the results reveal that family conflict resolution has a significant positive correlation with psychological wellbeing $(r=0.16 ; p<.01)$, showing that resolving conflict among conflicting parties in the families of married career women in Ibadan, Nigeria increases the level of their psychological wellbeing. This paper confirms the fifth hypothesis due to the abovestated results. 


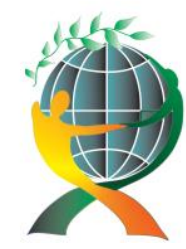

\author{
(online) $=$ ISSN $2285-3642$ \\ ISSN-L = $2285-3642$ \\ Journal of Economic Development, Environment and People \\ Volume 10, Issue 3, 2021
}

URL: http://jedep.spiruharet.ro

E-mail : office jedep@spiruharet.ro

\title{
Hypothesis six
}

This hypothesis stated that family conflict resolution significantly moderates psychological distress, social support, and domestic violence in sustaining psychological wellbeing among married women in Ibadan, Nigeria. This paper tested this hypothesis using stepwise multiple regression analysis. The results are in Table 3.

Table 3: Summary of stepwise regressions showing the moderating effect of family conflict resolution on psychological distress, perceived social support, and domestic violence as factors influencing the sustainability of psychological wellbeing amongst married career women in Ibadan, Nigeria.

\begin{tabular}{|c|c|c|c|c|c|c|c|c|}
\hline & Predictors & Beta( $\beta)$ & $\mathbf{T}$ & Sig & $\mathbf{R}$ & $\mathbf{R}^{2}$ & $\mathbf{F}$ & $\mathbf{P}$ \\
\hline \multirow{2}{*}{\multicolumn{2}{|c|}{1 (Constant) }} & & 42.238 & .000 & & & & \\
\hline & & 410 & 7.485 & .000 & $.410^{\mathrm{a}}$ & 168 & 56.018 & $.000^{\mathrm{b}}$ \\
\hline \multirow[t]{3}{*}{2} & (Constant) & & 41.181 & .000 & & & & \\
\hline & Social Support & .673 & 8.281 & .000 & & & & \\
\hline & Family Conflict Resolution & .348 & 4.283 & .000 & $.468^{b}$ & 219 & 38.930 & $.000^{c}$ \\
\hline \multirow[t]{4}{*}{3} & (Constant) & & 24.257 & .000 & & & & \\
\hline & Social Support & .668 & 7.998 & .000 & & & & \\
\hline & Family Conflict Resolution & .345 & 4.214 & .000 & & & & \\
\hline & Psychological Distress & -.017 & -.311 & .756 & $.469^{c}$ & .220 & 25.901 & $.000^{\mathrm{d}}$ \\
\hline \multirow[t]{5}{*}{4} & (Constant) & & 16.818 & .000 & & & & \\
\hline & Social Support & .677 & 8.123 & .000 & & & & \\
\hline & Family Conflict Resolution & .361 & 4.394 & .000 & & & & \\
\hline & Psychological Distress & .007 & 125 & .901 & & 229 & 20.403 & 000 e \\
\hline & Domestic Violence & .099 & 1.809 & .072 & $.478^{\mathrm{d}}$ & .229 & 20.403 & $.000^{\circ}$ \\
\hline
\end{tabular}

a. Dependent Variable: Psychological Wellbeing

b. Predictors: (Constant), Social Support

c. Predictors: (Constant), Social Support, Conflict Resolution

d. Predictors: (Constant), Social Support, Conflict Resolution, Psychological Distress

e. Predictors: (Constant), Social Support, Conflict Resolution, Psychological Distress, Domestic Violence

The results shown in Table 3 indicate that the first model, including social support, contributed $16.8 \%$ variance $\left(R=.410, R^{2}=.168, F=56.018, P<.01\right)$ in the psychological wellbeing of married career women in Ibadan, Nigeria. Besides, the second model, including family conflict resolution, yielded a higher variance of about $21.9 \%(\mathrm{R}=.468, \mathrm{R} 2=.219, \mathrm{~F}=38.93, \mathrm{P}<.01)$ in the psychological wellbeing of married career women in Ibadan, Nigeria. The third model, including psychological distress, yielded a $22 \%$ variance $(R=.469, R 2=.220$, $\mathrm{F}=25.901, \mathrm{P}<.01)$ in the psychological wellbeing of married career women in Ibadan, Nigeria. However, further observations showed that psychological distress had lost its influence in the model, and it was not significant due to the moderating role of family conflict resolution. Also, the fourth model, including domestic violence, indicates that both psychological distress and domestic violence did not influence the psychological wellbeing of married career women in Ibadan, Nigeria. This result is due to the presence of family conflict resolution, as the model yielded a $23 \%$ variance $(\mathrm{R}=.478, \mathrm{R} 2=.229, \mathrm{~F}=20.403, \mathrm{P}<.01)$ in the psychological 


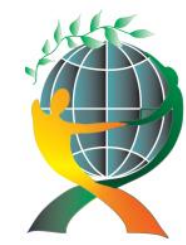

\author{
(online) $=$ ISSN $2285-3642$ \\ ISSN-L = $2285-3642$ \\ Journal of Economic Development, Environment and People \\ Volume 9, Issue 2, 2019 \\ URL: http://jedep.spiruharet.ro \\ E-mail : office jedep@spiruharet.ro
}

wellbeing of married career women in Ibadan, Nigeria. Therefore, the results supported the stated hypothesis.

\title{
Hypothesis seven
}

This proposition stated that demographic factors (for instance, age, religion, marital status, educational qualifications, and ethnicity) jointly and independently influence the sustenance of psychological wellbeing amongst married career women in Ibadan, Nigeria. This study tested the hypothesis using multiple regression analysis, and the results are in Table 4 below.

Table 4: Multiple regressions showing the influence of socio-demographic factors in sustaining psychological wellbeing among married career women in Ibadan, Nigeria

\begin{tabular}{|c|c|c|c|c|c|c|c|}
\hline Predictors & $\beta$ & t-value & Sig & $\mathbf{R}$ & $\mathrm{R}^{2}$ & $F(5,271)$ & $\mathbf{P}$ \\
\hline Age & .097 & 1.159 & $>.05$ & & & & \\
\hline Ethnicity & .118 & 1.898 & $>.05$ & & & & \\
\hline Marital Status & .129 & 1.536 & $>.05$ & .265 & .070 & 4.081 & $<.01$ \\
\hline Religion & -.170 & -2.891 & $<.01$ & & & & \\
\hline Educational Qualification & -.187 & -2.602 & $>.05$ & & & & \\
\hline
\end{tabular}

Dependent Variable: Psychological Wellbeing

The result stated in Table 4 indicates that socio-demographic factors jointly predicted psychological wellbeing amongst married career women in Ibadan, Nigeria at $\left(R=.265, R^{2}=.070, F(5,271)=4.081 ; P<.01\right)$. This result implies that age, ethnicity, marital status, religion, and highest educational qualifications accounted for about 7\% psychological wellbeing variance amongst married career women in Ibadan, Nigeria. Furthermore, the results revealed that only religion had a significant independent (main) influence on the sustenance of psychological wellbeing $(\beta=-.170, t=-2.891, p<.01)$ amongst married career women in Ibadan, Nigeria. Therefore, the results largely support the stated hypothesis. However, this result requires further clarifications on the influence of religion on psychological wellbeing using a one-way ANOVA, as presented in table 5 below:

Table 5: Summary of the one-way ANOVA showing the influence of religion in sustaining psychological wellbeing among married career women in Ibadan, Nigeria.

\begin{tabular}{|c|cccc|}
\hline \multicolumn{1}{|l|}{ Psychological Wellbeing } & & & & \\
\hline Sum of Squares & df & Mean Square & F & Sig. \\
\hline
\end{tabular}




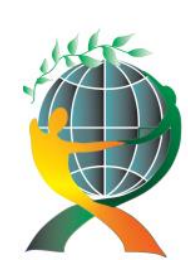

$$
\begin{gathered}
\text { (online) }=\text { ISSN } 2285-3642 \\
\text { ISSN-L = 2285 - } 3642
\end{gathered}
$$

Journal of Economic Development, Environment and People

Volume 10, Issue 3, 2021

URL: http://jedep.spiruharet.ro

\begin{tabular}{|c|c|c|c|c|c|}
\hline $\begin{array}{l}\text { Between Groups } \\
\text { Within Groups }\end{array}$ & $\begin{array}{l}2493.937 \\
61369.935\end{array}$ & $\begin{array}{c}2 \\
277\end{array}$ & $\begin{array}{l}1246.968 \\
221.552\end{array}$ & 5.628 & .004 \\
\hline Total & 63863.871 & 279 & & & \\
\hline
\end{tabular}

E-mail : office jedep@spiruharet.ro

Table 5 indicates that religion had a significant influence on the psychological wellbeing amongst married career women in Ibadan at $(F(2,277)=5.628 ; \mathrm{P}<.01)$. Besides, this paper conducted a Post-Hoc analysis of HSD- Highest Significant Difference.

Table 6: Summary of HSD multiple comparison analysis showing the influence of religion on psychological wellbeing amongst married career women in Ibadan, Nigeria.

\begin{tabular}{|l|cccc|}
\hline Religion I-J & $\mathbf{1}$ & $\mathbf{2}$ & $\mathbf{3}$ & $\bar{X}$ \\
\hline 1. Christian & 1 & $-6.20225^{*}$ & 1.01337 & 63.94 \\
2. Islam & & 1 & -5.18888 & 66.96 \\
3. Others & & & 1 & 64.75 \\
\hline
\end{tabular}

* The mean difference is significant at the 0.05 level.

The post-hoc results presented in table 6 indicate that married career women who practice Islamic religion reported significantly highest psychological wellbeing (Mean=67; $p<.05$ ) compared to the married career women who practice Christianity and Others. Thus, the result established the influence of religion on psychological wellbeing amongst married career women in Ibadan, Nigeria, and thus confirmed the seventh hypothesis.

\section{Discussions}

The results stated above showed that the psychological distress of married career women does not sustain their psychological wellbeing. It also reduces the psychological wellbeing of married career women in Ibadan. Besides, the stated results confirmed that the psychological wellbeing of married career women increases and remains sustained with adequate social support and family conflict resolution. As mentioned above, Mark and Smith (2011) investigated the relationship between psychological distress and coping in predicting employees' psychological wellbeing. They opined that poor wellbeing correlated with increased levels of psychological distress. The current study also supports Caverley's (2005) findings, who indicated that distressed employees are more likely to be weak and less motivated, less safe at work, and unhealthy, negatively affecting their psychological and emotional wellbeing. Besides, the above results confirmed that an increase in the social support married career women in Nigeria receive, the higher their psychological wellbeing. Hence, the current investigation confirms the position of Gyasi et al. (2018), who opined that numerous parts of significant social care: emotional bonds, attending social events, couple-focused, family/friends contacts, and remittances from children significantly relate to improved psychological 


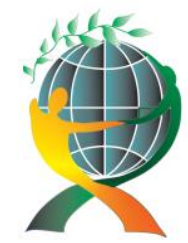

\author{
(online) $=$ ISSN $2285-3642$ \\ ISSN-L = $2285-3642$ \\ Journal of Economic Development, Environment and People \\ Volume 9, Issue 2, 2019
}

URL: http://jedep.spiruharet.ro

E-mail : office jedep@spiruharet.ro

wellbeing. The above-stated results indicated that resolving conflict among conflicting parties in the families of married career women in Ibadan, Nigeria, increases their psychological wellbeing. Hence, this paper confirms the submissions of Panatik et al. (2011), who discovered a meaningful positive relationship between conflict resolution and the psychological wellbeing of the family, and Reich et al. (2007), who noted a significant relationship between the right conflict management style and psychological wellbeing within the family. Therefore, reduced psychological distress increases social support, and consistent family conflict resolution will improve and sustain the psychological wellbeing of married career women in Ibadan, Nigeria. Hence, this paper has achieved its first objectives to examine relationships among psychological distress, social support, domestic violence, family conflict resolution, and psychological wellbeing among married career women in Nigeria.

Furthermore, the results specified above showed that psychological distress, social support, domestic violence, and family conflict resolution jointly predicted the psychological wellbeing among married career women in Ibadan, Nigeria. They imply that psychological distress, social support, domestic violence, and family conflict resolution accounted for $23 \%$ of the changes observed in the self-reported psychological wellbeing level among married career women. In comparison, the remaining $76.7 \%$ is attributed to other factors not considered in this study. Further findings showed the significant independent contributions of each independent variable to the variance in the dependent variable: psychological distress contributed about $11 \%$ variance in psychological wellbeing social support contributed about $68 \%$ variance, domestic violence contributed about $10 \%$ variance, while family conflict resolution contributed about $36 \%$ variance in the psychological wellbeing of married career women in Ibadan, Nigeria.

As stated earlier, Frone et al. (2013) established that psychological distress is a significant predictor of psychological wellbeing having harmful effects on individuals' health and wellbeing. Besides, this paper corroborates Jackson and Slater (2016), who stated that psychological distress and work-life balance significantly and independently predict psychological wellbeing and a healthy lifestyle. The earlier-stated results support Mohammed's (2010) position that physical exercise, psychological distress, and work-life balance were significant psychological wellbeing predictors. The results also support Lee, Tzeng, and Chiang (2019), who indicated psychological distress as the primary predictor of nurses' psychological wellbeing. Also, the earlier-stated results of this paper verify the position of Ryska \& Yin (1999); Reed \& Giacobbi (2004); and Malinauskas (2010), who indicated that social support predicted psychological wellbeing among married women. This is because social support from friends and family increases physio-psychological wellbeing and decreases stress among working women. The current results also validate Feldman et al. (2000) findings, who specified that women's social support systems seriously influence their psychological wellbeing in different ways. As aforementioned, Adejumo (2008) noted a significant independent influence of social support on the psychological wellbeing of career women in Ibadan, Nigeria. The current results corroborate Afroz's (2016) position, who opined that social support positively impacts the occupied roles of women at workplaces by creating an equilibrium between family and work, making them ardently proficient in abolishing family-work struggles and enhancing psychological wellbeing.

This paper also confirms the position of Cole et al. (2002), who noted that family conflict resolution was a moderating factor that suppressed partner violence and aggression on psychological wellbeing. Besides, Amiri (2006) confirmed that family conflict resolution was a moderator of psychological wellbeing. Therefore, reduced psychological distress, increased social support, reduced domestic violence, and consistent family 


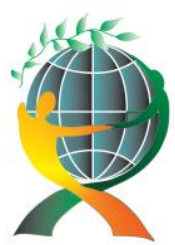

\author{
(online) $=$ ISSN $2285-3642$ \\ ISSN-L = $2285-3642$ \\ Journal of Economic Development, Environment and People \\ Volume 10, Issue 3, 2021 \\ URL: http://jedep.spiruharet.ro \\ E-mail : office jedep@spiruharet.ro
}

conflict resolution are significant influencers in sustaining the psychological wellbeing of married career women in Ibadan, Nigeria. Hence, this paper has achieved its second objective to investigate psychological distress, social support, domestic violence, and family conflict resolution as factors influencing psychological wellbeing among married career women in Ibadan, Nigeria.

Moreover, this paper shows that the first result model, including social support, contributed to a $16.8 \%$ variance in the psychological wellbeing of married women in Ibadan, Nigeria. In the second model, adding family conflict resolution to social support in examining psychological wellbeing variance yielded a higher variance of about $21.9 \%$ in psychological wellbeing among married career women. This result infers that the psychological wellbeing of married career women in Ibadan, Nigeria, is better sustained by intensifying conflict resolution within their families. Besides, in the third model, introducing psychological distress yielded a $22 \%$ variance in psychological wellbeing among married women in Ibadan, Nigeria, which is not significantly different from the variance achieved by introducing family conflict resolution. Hence, psychological distress had lost its influence in the model, and it was not significant due to the moderating role of family conflict resolution. Also, the fourth model, including domestic violence, indicates that psychological distress and domestic violence did not predict psychological wellbeing among married career women in Ibadan, Nigeria; because of family conflict resolution, having the model yield a $23 \%$ variance in their psychological wellbeing. Notably, the current study has established family conflict resolution as a significant moderator of the harmful influence of psychological distress, social support, and domestic violence in sustaining psychological wellbeing amongst married career women in Ibadan, Nigeria. Family conflict resolution remains the most influential significant influencer in sustaining psychological wellbeing amongst married career women in Ibadan, Nigeria. This paper has also achieved its third objective, finding out if family conflict resolution will significantly moderate psychological distress, social support, and domestic violence in sustaining psychological wellbeing amongst married career women in Ibadan, Nigeria.

Besides, this paper affirms that out of the socio-demographic factors (age, marital status, religion, and educational qualification) examined as influencers in sustaining psychological wellbeing amongst married career women in Ibadan, Nigeria, only religion had a significant independent influence sustaining psychological wellbeing. This paper confirms the position of (Francis \& Kaldor, 2002; Keyes \& Reitzes, 2007; Greenfield \& Marks 2007), who posited that the frequency of attendance at religious services correlated with greater psychological wellbeing. It also corroborates (Pargament et al., 2001; Wink et al., 2005; Greenfield \& Marks 2007; Keyes \& Reitzes 2007) in their assertion that religion has been linked to both physical and psychological wellbeing. Also, the present researcher conducted a Post-Hoc analysis of HSD (Highest Significant Difference), and the results indicate that married women who are practicing Islamic religion reported the highest psychological wellbeing compared to those who practice Christianity and other religions. The current study has also achieved its fourth objective to determine demographic factors (such as age, religion, marital status, and educational qualifications) as influencing factors for sustaining the psychological wellbeing amongst married career women in Ibadan, Nigeria. 


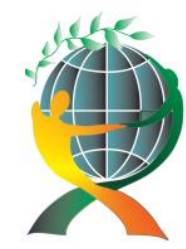

\author{
(online) $=$ ISSN $2285-3642$ \\ ISSN-L = $2285-3642$ \\ Journal of Economic Development, Environment and People \\ Volume 9, Issue 2, 2019
}

URL: http://jedep.spiruharet.ro

E-mail : office jedep@spiruharet.ro

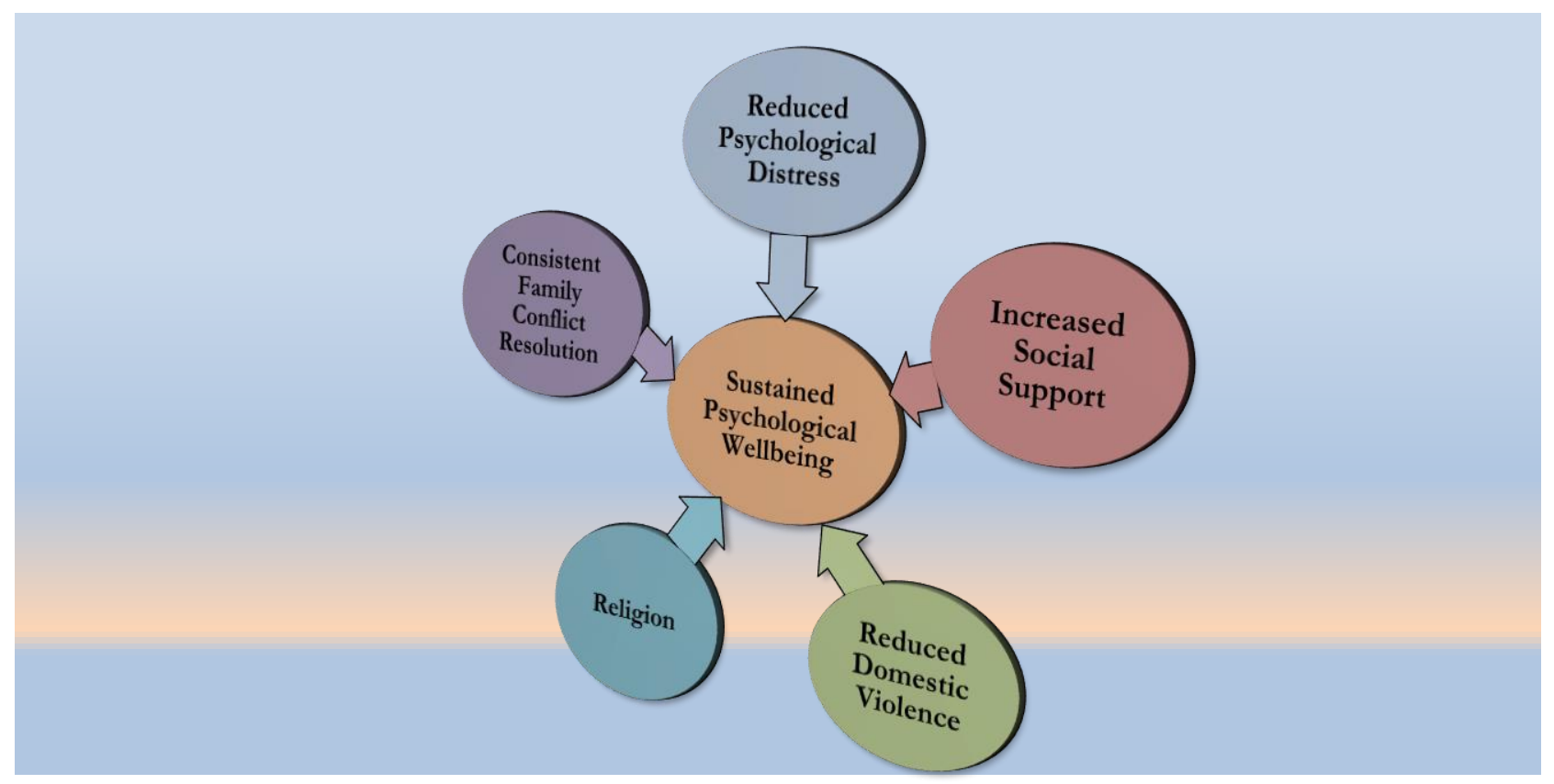

Figure 1: Practical model of sustaining psychological wellbeing amongst married career women in Ibadan, Nigeria.

\title{
Practical implications
}

The current findings have several implications for further research and appropriate clinical and developmental strategic intervention necessary for reducing psychological distress, improving family therapy, social support, marital counseling, and health promotion among families in every society. These results will also have direct implications on the entire family's wellbeing, including husband and children.

\section{Conclusion}

This paper's main goal was to examine how to sustain the psychological wellbeing of married career women in Ibadan, Nigeria, by looking into psychological distress, social support, domestic violence, and family conflict resolution as influencers. Based on its results, reduced psychological distress, social support, reduced domestic violence, and consistent family conflict resolution jointly and independently influenced the sustenance of psychological wellbeing amongst married career women in Ibadan, Nigeria.

Moreover, this study has found that family conflict resolution significantly played a moderating role in the influence of psychological distress, social support, and domestic violence on the sustenance of psychological wellbeing amongst married career women in Ibadan, Nigeria. The current findings established that the effect of psychological distress and domestic violence on psychological wellbeing amongst married career women came to a non-significant level in the presence of family conflict resolution as the moderating influence. Therefore, this study concludes that family conflict resolution has a significant moderating influence on negative predictors of the psychological wellbeing of married career women in Ibadan, Nigeria. The paper 


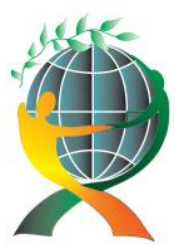

\author{
(online) $=$ ISSN $2285-3642$ \\ ISSN-L = $2285-3642$ \\ Journal of Economic Development, Environment and People \\ Volume 10, Issue 3, 2021 \\ URL: http://jedep.spiruharet.ro \\ E-mail : office jedep@spiruharet.ro
}

further concluded that married career women's religion significantly influences psychological wellbeing among married career women in Ibadan, Nigeria.

Hence, this paper would like to assert that reduced psychological distress, increased social support, reduced domestic violence, and consistent family conflict resolution significantly supports psychological wellbeing among married career women in Ibadan, Nigeria. At the same time, their religious beliefs also influence their psychological wellbeing.

\title{
8. Recommendations
}

This paper recommends that the leadership and management of work organizations should always endeavor to make every work environment more conducive and ensure that workload and work culture do not induce psychological distress.

Also, social support tends to improve the sustenance of psychological wellbeing amongst married career women in Ibadan, Nigeria. This finding suggests that family, friends, and significant others should know that social support in the form of advice, helpful information, and handling family issues would significantly help married couples maintain a healthy relationship. This step would improve and sustain their psychological wellbeing.

More than that, it is imperative to propose that all hands be on deck to ensure adequate support for married career women through other means, not limited to information or material support alone. This support may include financial support and counseling, education, modeling excellent and workable family conflict resolution techniques. Hence, this paper recommends that developmental psychologists incorporate intervention containing family conflict resolution methods in their services to married individuals and the ones in courtship to reassure them of better psychological wellbeing before long.

Furthermore, domestic violence's devastating effects on psychological wellbeing have become one major area of practical intervention for both career men and women in marriage to pursue healthy family development. Hence, the government should focus on intervention programs that reduce domestic violence within society at every level. This study also recommends that further investigations should replicate the current study by combining interview methods with a survey method to widen the scope of the present study. Also, future researchers should include both men and women in replicating the current research to control gender biases.

\section{References}

[1] Adebayo, A. A. (2014). Domestic violence against men: Balancing gender issues in Nigeria. American Journal of Sociological Research, 4(1), 14-19.

[2] Adejumo, A. O. (2008). Influence of social support, work overload, and parity on pregnant career women's psychological well-being. Journal of Applied Biobehavioral Research, 13(4), 215-228.

[3] Afolabi, F. J., \& Aina, O. I. (2014). Gender differentials in subjective wellbeing among religious elderly Yoruba people in southwest Nigeria. Ageing International, 39(2), 180-193.

[4] Afroz, N. (2016). Emotional intelligence, social support, and general wellbeing of working and non-working Muslim women. International Journal of Indian Psychology, 3 (3), 6-19. 


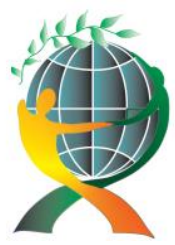

\author{
(online) $=$ ISSN $2285-3642$ \\ ISSN-L = $2285-3642$ \\ Journal of Economic Development, Environment and People \\ Volume 9, Issue 2, 2019 \\ URL: http://jedep.spiruharet.ro \\ E-mail : office jedep@spiruharet.ro
}

[5] Al-Windi, A., Elmfeldt, D., Tibblin, G., \& Svärdsudd, K. (1999). The influence of socio-demographic characteristics on wellbeing and symptoms in a Swedish community: Results from a postal questionnaire survey. Scandinavian Journal of Primary Health Care, 17(4), 201-209.

[6] Amiri, M. (2006). Exploring awareness, attitude, and performance of managers at the Shahrood Medical University of Sciences in the area of conflict management styles. Magazine of Danesh Ofogh, 4(12): 50-56.

[7] Bougie, E., Arim, R. G., Kohen, D. E., \& Findlay, L. C. (2016). Validation of the 10-item Kessler psychological distress scale (K10) in the 2012 aboriginal people's survey. Health Reports, 27(1), 3-11.

[8] Brake, E. (2011). Minimizing Marriage: Marriage, morality, and the law Oxford University Press.

[9] Brandberg, Y., Bolund, C., Sigurdardottir, V., Sjödén, P., \& Sullivan, M. (1992). Anxiety and depressive symptoms at different stages of malignant melanoma. Psycho-oncology, 1(2), 71-78.

[10] Caverley, N. (2005). Civil service resiliency and coping. International Journal of Public Sector Management,

[11] Cole, D. C., Ibrahim, S., Shannon, H. S., Scott, F. E., \& Eyles, J. (2002). Work and life stressors and psychological distress in the Canadian working population: A structural equation modeling approach to the 1994 national population health survey analysis. Chronic Diseases and Injuries in Canada, 23(3), 91.

[12] Cunradi, C. B., Mair, C., \& Todd, M. (2014). Alcohol outlet density, drinking contexts, and intimate partner violence: A review of environmental risk factors. Journal of Drug Education, 44(1-2), 19-33.

[13] Cutrona, C. E., Cole, V., Colangelo, N., Assouline, S. G., \& Russell, D. W. (1994). Perceived parental social support and academic achievement: An attachment theory perspective. Journal of Personality and Social Psychology, 66(2), 369.

[14] De Dreu, C. K., \& Beersma, B. (2005). Conflict in organizations: Beyond effectiveness and performance. European Journal of Work and Organizational Psychology, 14(2), 105-117.

[15] Deelstra, J. T., Peeters, M. C., Schaufeli, W. B., Stroebe, W., Zijlstra, F. R., \& van Doornen, L. P. (2003). Receiving instrumental support at work: When help is not welcome. Journal of Applied Psychology, $88(2), 324$.

[16] Dorji, N., Dunne, M., \& Gurung, M. (2019). Socio-demographic correlates of psychological wellbeing among older adults in Bhutan.

[17] Edmondson, O. J., \& MacLeod, A. K. (2015). Psychological wellbeing and anticipated positive personal events: Their relationship to depression. Clinical Psychology \& Psychotherapy, 22(5), 418-425.

[18] Fawole, O. I., Aderonmu, A. L., \& Fawole, A. O. (2005). Intimate partner abuse: Wife beating among civil servants in Ibadan, Nigeria. African Journal of Reproductive Health, 54-64.

[19] Feldman, P. J., Dunkel-Schetter, C., Sandman, C. A., \& Wadhwa, P. D. (2000). Maternal social support predicts birth weight and fetal growth in human pregnancy. Psychosomatic Medicine, 62(5), 715-725.

[20] Ferreira, N. (2012). Hardiness about organizational commitment in the human resource management field. SA Journal of Human Resource Management, 10(2), 1-10.

[21] Field, C. A., \& Caetano, R. (2004). Ethnic differences in intimate partner violence in the US general population: The role of alcohol use and socioeconomic status. Trauma, Violence, \& Abuse, 5(4), 303317.

[22] Francis, L. J., \& Kaldor, P. (2002). The relationship between psychological wellbeing and Christian faith and practice in an Australian population sample. Journal for the Scientific Study of Religion, 41(1), 179184 


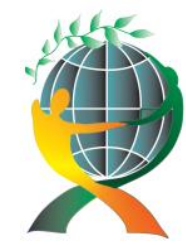

\author{
(online) $=$ ISSN $2285-3642$ \\ ISSN-L = $2285-3642$ \\ Journal of Economic Development, Environment and People \\ Volume 10, Issue 3, 2021 \\ URL: http://jedep.spiruharet.ro \\ E-mail : office jedep@spiruharet.ro
}

[23] Frone, M. R., Russell, M., \& Cooper, M. L. (1997). Relation of work-family conflict to health outcomes: A four-year longitudinal study of employed parents. Journal of Occupational and Organizational Psychology, 70(4), 325-335.

[24] George, R. P. (2001). Same-sex marriage and moral neutrality. Marriage and the Common Good, 81-98.

[25] Golding, J. M. (1999). Intimate partner violence as a risk factor for mental disorders: A meta-analysis. Journal of Family Violence, 14(2), 99-132.

[26] Greenfield, E. A., \& Marks, N. F. (2007). Religious, social identity as an explanatory factor for associations between more frequent formal religious participation and psychological wellbeing The International Journal for the Psychology of Religion, 17(3), 245-259.

[27] Gyasi, R. M., Phillips, D. R., \& Abass, K. (2019). Social support networks and psychological wellbeing in community-dwelling older Ghanaian cohorts. International Psychogeriatrics, 31(7), 1047-1057.

[28] Harshpinder. (2006). Physiological and Psychological Stressors among working and non-working women. Journal of Human Ecology, 20(2), 121-123.

[29] Hartley, C., \& Watson, L. (2012). Political liberalism, marriage, and family. Law and Philosophy, 31(2), 185-212.

[30] Jackson, M. A., \& Slater, S. (2016). Twenty-eight (28) hidden biases in counseling women: Balancing work and family concerns. Handbook of Counseling Women,

[31] Karatepe, O. M., \& Tekinkus, M. (2006). The effects of work-family conflict, emotional exhaustion, and intrinsic motivation on job outcomes of front-line employees. International Journal of Bank Marketing,

[32] Kessler, R. C., Andrews, G., Colpe, L. J., Hiripi, E., Mroczek, D. K., Normand, S., Zaslavsky, A. M. (2002). Short screening scales to monitor population prevalence and trends in non-specific psychological distress. Psychological Medicine, 32(6), 959-976.

[33] Keyes, C. L. (2002). The mental health continuum: From languishing to flourishing in life. Journal of Health and Social Behavior, 207-222.

[34] Keyes, C., \& Reitzes, D. C. (2007). The role of religious identity in the mental health of older working and retired adults. Aging and Mental Health, 11(4), 434-443.

[35] Khumalo, I., Temane, Q., \& Wissing, M. (2012). Socio-demographic variables, general psychological wellbeing and the mental health continuum in an African context. Social Indicators Research, 105(3), 419-442.

[36] Kreitner, R., \& Kinicki, A. (2005). Organizational behavior. Jakarta: Four Salemba

[37] Lee, Y., \& Lee, H. (2015). Role conflict and conflict management styles of hospital nurses. Korean Journal of Stress Research, 23(3), 147-158.

[38] Lee, T. S., Tzeng, W., \& Chiang, H. (2019). Impact of coping strategies on nurses' wellbeing and practice. Journal of Nursing Scholarship, 51(2), 195-204.

[39] Lincoln, K. D., Taylor, R. J., Chae, D. H., \& Chatters, L. M. (2010). Demographic correlates of psychological wellbeing and distress among older African Americans and Caribbean black adults. Best Practices in Mental Health, 6(1), 103-126.

[40] Longman (2017). Longman Dictionary of Contemporary English.

[41] Lorenzo-Blanco, E. I., Meca, A., Unger, J. B., Romero, A., Szapocznik, J., Piña-Watson, B., Des Rosiers, S. E. (2017). Longitudinal effects of Latino parent cultural stress, depressive symptoms, and family functioning on youth emotional wellbeing and health risk behaviors. Family Process, 56(4), 981-996.

[42] Malinauskas, R. (2010). The associations among social support, stress, and life satisfaction as perceived by injured college athletes. Social Behavior and Personality: An International Journal, 38(6), 741-752. 


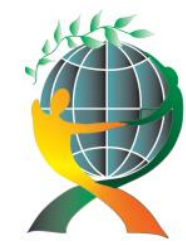

\author{
(online) $=$ ISSN $2285-3642$ \\ ISSN-L = $2285-3642$ \\ Journal of Economic Development, Environment and People \\ Volume 9, Issue 2, 2019
}

URL: http://jedep.spiruharet.ro

E-mail : office jedep@spiruharet.ro

[43] Mark, G., \& Smith, A. P. (2012). Effects of occupational stress, job characteristics, coping, and attributional style on university employees' mental health and job satisfaction. Anxiety, Stress \& Coping, 25(1), 63-78.

[44] Maslach, C., \& Leiter, M. P. (2014). Ten (10) burnout in the workplace. Paper presented at the Psychology Serving Humanity: Proceedings of the 30th International Congress of Psychology: Volume 2: Western Psychology, 2116.

[45] Mirowsky, J., \& Ross, C. E. (2007). Creative work and health. Journal of Health and Social Behavior, 48(4), 385-403.

[46] Mohammed, E. F., Unher, M., \& Sugawara, M. (2010). Psychological wellbeing: A comparative study between Japanese and Egyptian students. Psychologia, 53(2), 68-85.

[47] Mone, E., Eisinger, C., Guggenheim, K., Price, B., \& Stine, C. (2011). Performance management at the wheel: Driving employee engagement in organizations. Journal of Business and Psychology, 26(2), 205212.

[48] Narayanan, G., \& Rao, K. (2004). Predictors of psychological distress in college students: The role of attachment styles, parental bonding, personality, and coping. Indian Journal of Clinical Psychology, 31(2), 100.

[49] Oluwagbemiga, O. (2016). Effect of social support systems on the psychosocial wellbeing of the elderly in older people's homes in Ibadan. Journal of Gerontology and Geriatric Research, 5, 343.

[50] Panatik, S. A. B., Badri, S. K. Z., Rajab, A., Rahman, H. A., \& Shah, I. M. (2011). The impact of work-family conflict on psychological wellbeing among school teachers in Malaysia. Procedia-Social and Behavioral Sciences, 29, 1500-1507.

[51] Pargament, K. I., Tarakeshwar, N., Ellison, C. G., \& Wulff, K. M. (2001). Religious coping among the religious: The relationships between religious coping and wellbeing in a national sample of Presbyterian clergy, elders, and members. Journal for the Scientific Study of Religion, 40(3), 497-513.

[52] Parveen, N. (2009). Investigating occupational stress among married and unmarried working women in Hyderabad city. Bahria Journal of Professional Psychology, 5, 21-37.

[53] Reed, S., \& Giacobbi, P. R., Jr. (2004). The stress and coping responses of certified graduate athletic training students. Journal of Athletic Training, 39(2), 193-200.

[54] Reich, W. A., Wagner-Westbrook, B. J., \& Kressel, K. (2007). Actual and ideal conflict styles and job distress in a health care organization. The Journal of Psychology, 141(1), 5-15.

[55] Ryff, C. D. (2014). Psychological wellbeing revisited: Advances in the science and practice of eudaimonia. Psychotherapy and Psychosomatics, 83(1), 10-28. doi: 10.1159/000353263

[56] Ryska, T. A., \& Yin, Z. (1999). Testing the buffering hypothesis: Perceptions of coach support and precompetitive anxiety among male and female high school athletes. Current Psychology, 18(4), 381-393.

[57] Scott, J., \& Marshall, G. (2009). A dictionary of sociology Oxford University Press, USA.

[58] Sori, C. F. (2007). "An affair to remember" Infidelity and its impact on children.

[59] Srimathi, N., \& Kiran Kumar, S. (2010). Psychological wellbeing of employed women across different organizations. Journal of the Indian Academy of Applied Psychology, 36(1), 89-95.

[60] Sugarman, D. B., \& Hotaling, G. T. (1997). Intimate violence and social desirability: A meta-analytic review. Journal of Interpersonal Violence, 12(2), 275-290.

[61] Thomas, P. A., Liu, H., \& Umberson, D. (2017). Family relationships and wellbeing. Innovation in Aging, $1(3)$, igx025. 


\author{
(online) $=$ ISSN $2285-3642$ \\ ISSN-L = $2285-3642$ \\ Journal of Economic Development, Environment and People \\ Volume 10, Issue 3, 2021 \\ URL: http://jedep.spiruharet.ro \\ E-mail : office jedep@spiruharet.ro
}

[62] Tjaden, P., \& Thoennes, N. (2000). Extent, nature, and consequences of intimate partner violence series. Prevention,

[63] Wallensteen, P. (2015). Quality peace: Peacebuilding, victory, and world order Oxford University Press.

[64] Wink, P., Dillon, M., \& Larsen, B. (2005). Religion as moderator of the depression-health connection: Findings from a longitudinal study. Research on Aging, 27(2), 197-220.

[65] World Health Organization. (2000). The world health report 2000: Health systems: Improving performance World Health Organization.

[66] World Health Organization. (2012). Good Health Adds Life to Years: Global Brief for World Health Day 2012,

[67] Zimet, G. D., Dahlem, N. W., Zimet, S. G., \& Farley, G. K. (1988). The multidimensional scale of perceived social support. Journal of Personality Assessment, 52(1), 30-41. 